\title{
Geometric Preferences in Iron(II) and Zinc(II) Model Complexes of Peptide Deformylase
}

\author{
Vivek V. Karambelkar ${ }^{\dagger}$, Chuanyun Xiao ${ }^{\ddagger}$, Yingkai Zhang ${ }^{\ddagger}$, Amy A. Narducci Sarjeant ${ }^{\dagger}$, and \\ David P. Goldberg $†$ \\ tDepartment of Chemistry, Johns Hopkins University, 3400 N. Charles Street, Baltimore, Maryland, \\ 21218 \\ ‡Department of Chemistry, New York University, New York, NY 10003
}

\section{Abstract}

A combination of experimental and theoretical studies on $\left(\mathrm{N}, \mathrm{S}(\right.$ thiolate) $) \mathrm{M}^{\mathrm{II}}$-formate complexes (M

$=\mathrm{Fe}, \mathrm{Zn}$ ) suggests a rationale for the metal ion dependence of peptide deformylase.

Based on active site structure (tetrahedral $\left(\mathrm{His}_{2} \mathrm{Cys}\right) \mathrm{M}^{\mathrm{II}}\left(\mathrm{OH}_{\mathrm{n}}\right)$ ), conserved sequence motifs, and function (hydrolysis), peptide deformylase (PDF) belongs to the mononuclear zinc(II) enzyme family. ${ }^{1}$ However, recent evidence shows bacterial PDF to be the first example of an iron(II) metallopeptidase, which hydrolyzes the formyl bond of the N-terminus of newly synthesized polypeptides. ${ }^{2-4}$ Intriguingly, the $\mathrm{Zn}^{\mathrm{II}}$ form of bacterial PDF is dramatically less active than the $\mathrm{Fe}^{\mathrm{II}}$ form, although their native structures are identical. ${ }^{4-6}$ The mechanism of this enzyme and an explanation of the metal-ion dependence are under investigation. PDF is also a target for new antibiotic agents, and therefore knowledge regarding its mechanism is of practical significance. ${ }^{7}$ We are involved in the synthesis of $\mathrm{Zn}^{\mathrm{II}}$ and $\mathrm{Fe}^{\mathrm{II}}$ model complexes of PDF to gain a better understanding of the mechanism and unusual metal dependence of this enzyme.

Previously we reported the synthesis of $(\mathrm{PATH}) \mathrm{Zn}^{\mathrm{II}}\left(\mathrm{O}_{2} \mathrm{CH}\right)$, a model complex of the putative (formate) $\mathrm{Zn}^{\mathrm{II}}$-PDF intermediate. ${ }^{8}$ Analysis of the bonding mode in this complex showed that the formate was coordinated in an anisobidentate fashion. It was suggested that this bonding mode, as opposed to a purely monodentate interaction, might slow down the displacement of formate by water in the final step of the catalytic cycle, and account for the low reactivity of Zn-PDF. Following this argument, it was expected that the analogous (formate)Fe ${ }^{\mathrm{II}}-\mathrm{PDF}$ would exhibit a monodentate bonding mode.

Recently, high-resolution X-ray structures of (formate) $\mathrm{M}^{\mathrm{II}}-\mathrm{PDF}(\mathrm{M}=\mathrm{Zn}, \mathrm{Fe})$ from Chan and coworkers have revealed bonding motifs in contrast to our prediction; monodentate coordination was observed in the case of $\mathrm{Zn}^{\mathrm{II}}$ and bidentate coordination was seen for $\mathrm{Fe}^{\mathrm{II}} .{ }^{9}$ In order to further address the question of geometric preference in $\mathrm{Zn}^{\mathrm{II}}$ - and $\mathrm{Fe}^{\mathrm{II}}$-formate model complexes, we have synthesized and structurally characterized the first iron(II)-formate complex with thiolate ligation, $\left(\mathrm{Py}_{2} \mathrm{~S}\right) \mathrm{Fe}^{\mathrm{II}}\left(\mathrm{O}_{2} \mathrm{CH}\right)(\mathbf{1})$, and have conducted high-level theoretical calculations on this complex and the related formate complexes $(\mathrm{PATH}) \mathrm{Zn}\left(\mathrm{O}_{2} \mathrm{CH}\right)$, $(\mathrm{PATH}) \mathrm{Fe}\left(\mathrm{O}_{2} \mathrm{CH}\right)$, and $\left(\mathrm{Py}_{2} \mathrm{~S}\right) \mathrm{Zn}\left(\mathrm{O}_{2} \mathrm{CH}\right)$. Geometry optimizations, including calculations in which the potential energy surface was scanned with respect to one of the formate oxygen-to-

Correspondence to: David P. Goldberg.

Supporting Information Available: Experimental and computational details and crystallographic data for compounds 1 - 3. This material is available free of charge via the Internet at http://pubs.acs.org. 
$\mathrm{M}^{\mathrm{II}}$ distances, provide detailed information regarding the preferred bonding mode in these complexes. Although $\mathbf{1}$ is not an exact replica of the enzyme, the trends discovered by comparing the experimental and theoretical results for this complex and the other formate complexes allow us to formulate a new hypothesis regarding the differences in reactivity of zinc(II) and iron(II) in the PDF active site. In addition, the syntheses of the new zinc(II)-formate complexes $\left[\left(\mathrm{Py}_{2} \mathrm{~S}\right) \mathrm{Zn}_{2}\left(\mathrm{O}_{2} \mathrm{CH}\right)_{3}\right](2)$ and $\left[\left(\mathrm{Py}_{2} \mathrm{~S}\right)_{2} \mathrm{Zn}_{3}\left(\mathrm{O}_{2} \mathrm{CH}\right)_{2}\right]\left(\mathrm{BF}_{4}\right)_{2}(3)$ are described.

The synthesis of 1 is shown in Scheme 1. Addition of $\left(\mathrm{Py}_{2} \mathrm{~S}^{-}\right) \mathrm{Na}^{+}$to ferrous formate in $\mathrm{MeOH}$ gives a cloudy, yellow solution which turns clear over $18 \mathrm{~h}$. Removal of the solvent under vacuum gives an orange solid which can be partly redissolved in toluene. Crystals of $\mathbf{1}$ were grown from $\mathrm{Et}_{2} \mathrm{O} /$ toluene, and an ORTEP diagram of $\mathbf{1}$ is shown in Figure 1. The iron center is in a five-coordinate geometry with the formate ligand occupying the axial position opposite the $\mathrm{N}$ (amine) donor. The $\mathrm{N}$ (pyridyl)- $\mathrm{Fe}^{\mathrm{II}}$ and $\mathrm{S}-\mathrm{Fe}^{\mathrm{II}}$ distances (Table 1) are in the normal range. The N(amine)-Fe $\mathrm{Fe}^{\mathrm{II}}$ distance of 2.366(4) $\AA$ is long, but is quite close to the related complexes $\left(\mathrm{Py}_{2} \mathrm{~S}\right) \mathrm{Fe}^{\mathrm{II} X}\left(\mathrm{X}=\mathrm{Br}, \mathrm{N}(\right.$ amine $)-\mathrm{Fe}^{\mathrm{II}}=2.387(1) \AA ; \mathrm{X}=\mathrm{Cl}(2.352(2) \AA) .{ }^{10}$ There is no obvious reason for the elongation of this bond in these complexes, and theoretical calculations show that another isomer of $\mathbf{1}$ with a more conventional $\mathrm{Fe}^{\mathrm{II}}-\mathrm{N}$ (amine) distance should be accessible (vide infra). Interestingly, the formate ligand is clearly monodentate with $\mathrm{Fe}-\mathrm{O}(2)=4.12 \AA$, and is in fact bound in an anti disposition. Analysis of the angles around $\mathrm{Fe}(1)(\tau=0.76)$ clearly shows the geometry is trigonal bipyramidal. ${ }^{11}$

The ${ }^{1} \mathrm{H}$ NMR spectrum of $\mathbf{1}$ in $\mathrm{CD}_{3} \mathrm{CN}$ exhibits reasonably sharp, paramagnetically shifted peaks over the range +78 to $-25 \mathrm{ppm}$, which is characteristic of a high-spin $\mathrm{Fe}^{\mathrm{II}}$ complex, and the pattern of peaks is similar to that observed for the complexes $\left(\mathrm{Py}_{2} \mathrm{~S}\right) \mathrm{Fe}^{\mathrm{II}} \mathrm{X}(\mathrm{X}=\mathrm{Br}, \mathrm{Cl})$. ${ }^{10}$ The IR data for 1 in the solid state (KBr) exhibits a strong peak at $1630 \mathrm{~cm}^{-1}$ assigned to the asymmetric stretch of the monodentate formate ligand. A similar peak is found in the IR spectrum of 1 in $\mathrm{CH}_{3} \mathrm{CN}$ at $1625 \mathrm{~cm}^{-1}$. The NMR and IR data suggest that the solid-state structure of $\mathbf{1}$ is retained in solution.

Attempts to synthesize the mononuclear zinc analog of $\mathbf{1}$ via commercially available $\mathrm{Zn}$ $\left(\mathrm{O}_{2} \mathrm{CH}\right)_{2} \cdot 2 \mathrm{H}_{2} \mathrm{O}$ and $\mathrm{Py}_{2} \mathrm{SH}$ led instead to the isolation of the dinuclear complex 2 (Scheme 1). The X-ray structure of 2 (Figure $\mathrm{S} 1$ ) shows that the $\mathrm{Py}_{2} \mathrm{~S}^{-}$ligand is coordinated in the expected tetradentate fashion, and the formate ligand is coordinated in the open site. However, unlike in 1, the thiolate and formate ligands bridge to a second tetrahedral $\mathrm{Zn}\left(\mathrm{O}_{2} \mathrm{CH}\right)_{2}$ unit. The distances around each zinc ion are unexceptional, including the $\mathrm{Zn}-\mathrm{N}$ (amine) distance of 2.264 (2) A. Suspecting that the dinuclear nature of $\mathbf{2}$ was a consequence of pre-formed structures from the $\mathrm{Zn}\left(\mathrm{O}_{2} \mathrm{CH}\right)_{2}$ starting material, an alternative approach involving self-assembly of $\mathrm{Zn}$ $\left(\mathrm{BF}_{4}\right)_{2} \bullet \mathrm{H}_{2} \mathrm{O}, \mathrm{NaO}_{2} \mathrm{CH}$, and $\mathrm{Py}_{2} \mathrm{SH}$ was investigated. As seen in Scheme 1, this method did result in a different structural motif, but instead of a mononuclear complex, the trinuclear complex 3 was obtained. The structure of $\mathbf{3}$ (Figure S2) reveals two terminal $\left(\mathrm{Py}_{2} \mathrm{~S}\right) \mathrm{Zn}^{\mathrm{II}}$ units bridged by formate and thiolate ligands to a central, tetrahedral zinc ion. The terminal zinc(II) units exhibit typical 5-coordinate geometries similar to that in $\mathbf{2}$.

To gain further insight into the geometric preferences of mononuclear zinc(II)-formate and iron(II)-formate complexes, DFT calculations using B3LYP hybrid exchange-correlation functional and 6-311G* basis set were performed on (PATH) $\mathrm{M}^{\mathrm{II}}\left(\mathrm{O}_{2} \mathrm{CH}\right)$, and $\left(\mathrm{Py}_{2} \mathrm{~S}\right)$ $\mathrm{M}^{\mathrm{II}}\left(\mathrm{O}_{2} \mathrm{CH}\right)(\mathrm{M}=\mathrm{Zn}, \mathrm{Fe})$. The X-ray structures of $(\mathrm{PATH}) \mathrm{Zn}\left(\mathrm{O}_{2} \mathrm{CH}\right)$ and $\mathbf{1}$ were used as starting points for the geometry optimizations of these compounds, as well as for the hypothetical species $(\mathrm{PATH}) \mathrm{Fe}\left(\mathrm{O}_{2} \mathrm{CH}\right)$ and $\left(\mathrm{Py}_{2} \mathrm{~S}\right) \mathrm{Zn}\left(\mathrm{O}_{2} \mathrm{CH}\right)$, respectively. Selected information for the optimized structures is given in Table 1. The optimized geometries for $\left(\mathrm{Py}_{2} \mathrm{~S}\right) \mathrm{M}^{\mathrm{II}}\left(\mathrm{O}_{2} \mathrm{CH}\right)$ where $\mathrm{M}=\mathrm{Fe}^{\mathrm{II}}$ or $\mathrm{Zn}^{\mathrm{II}}$ both show monodentate bonding for the formate ligand (isomer a, Table 1), as found for the X-ray structure of $\mathbf{1}$. However, the formate is coordinated in a syn, instead of an anti fashion, causing the $\mathrm{M}-\mathrm{O}(2)$ distances to deviate 
significantly from the X-ray structure of $\mathbf{1}$. The potential energy surface for these structures with respect to the $\mathrm{M}-\mathrm{O}(2)$ distance $(3.0-4.0 \AA$ ) is quite flat (Figure S3). At much shorter M$\mathrm{O}(2)$ distances, another isomer is found (isomer b, Table 1). For $\mathrm{M}=\mathrm{Fe}^{\mathrm{II}}$, isomer $\mathrm{b}$ is only slightly lower in energy $(1.2 \mathrm{kcal} / \mathrm{mol})$ than isomer a, but does exhibit a bidentate bonding mode. In contrast, for $\mathrm{M}=\mathrm{Zn}^{\mathrm{II}}$, the formate ligand in isomer $\mathrm{b}$ remains monodentate.

Additionally, the M-N(amine) distance is much shorter in isomer b for the Fe complex, while it remains relatively long for the $\mathrm{Zn}$ complex. These calculations indicate that there is a modest, but clear preference for higher coordination number with $\mathrm{Fe}^{\mathrm{II}}$ as compared to $\mathrm{Zn}$.

Such a preference is significantly more apparent for $(\mathrm{PATH}) \mathrm{M}^{\mathrm{II}}\left(\mathrm{O}_{2} \mathrm{CH}\right)($ Table 1$)$. The optimized geometry of $(\mathrm{PATH}) \mathrm{Zn}^{\mathrm{II}}\left(\mathrm{O}_{2} \mathrm{CH}\right)$ is similar to its $\mathrm{X}$-ray structure, which shows an anisobidentate bonding mode. However, a distinct shift to bidentate coordination is seen in the optimized structure of (PATH) $\mathrm{Fe}^{\mathrm{II}}\left(\mathrm{O}_{2} \mathrm{CH}\right)$ (Figure 2). Quantitation of this effect can be seen in the potential energy surface plots for $(\mathrm{PATH}) \mathrm{M}^{\mathrm{II}}\left(\mathrm{O}_{2} \mathrm{CH}\right)$ versus $\mathrm{M}-\mathrm{O}(2)$ distance (Figure 3 ). This curve has a much sharper minimum for $\mathrm{Fe}^{\mathrm{II}}$ than for $\mathrm{Zn}^{\mathrm{II}}$, and the equilibrium position for $\mathrm{Fe}-\mathrm{O}(2)$ is $2.32 \AA$, within bonding distance. The energy minimum for $\mathrm{Zn}-\mathrm{O}(2)=2.81 \AA$, although the relative energy changes by only $0.5 \mathrm{kcal} / \mathrm{mol}$ as $\mathrm{Zn}-\mathrm{O}(2)$ varies between $2.2-$ $3.3 \AA$. Thus there is a clear preference for bidentate bonding of the formate ligand with iron (II) and hence higher coordination number, while for zinc(II) the geometry is flexible and there is no bonding mode preference.

The role of the metal ion in PDF, as in other hydrolytic enzymes, may include activation of a water molecule to furnish a nucleophilic hydroxide in proximity to the substrate (Scheme 2a), or electrophilic activation of both $\mathrm{H}_{2} \mathrm{O}$ and the substrate through coordination of the formyl group prior to hydrolysis (Scheme 2b). ${ }^{12}$ In the latter case, the metal ion also induces a proximity effect by bringing both reactants into the inner coordination sphere while proceeding through a five-coordinate intermediate. If other factors are held constant, the mechanism shown in Scheme $2 b$ should lead to higher enzymatic activity. Moreover, Scheme 2a produces a monodentate formate product while Scheme $2 b$ leads to bidentate bonding. A possible explanation for the dramatic reactivity difference between bacterial $\mathrm{Zn}$ - and $\mathrm{Fe}^{\mathrm{II}}-\mathrm{PDF}$ is that the iron(II) enzyme operates through the more efficient mechanism of Scheme $2 b$, while the zinc(II) enzyme functions through Scheme 2a.

We suggest that there is a distinct preference for coordination number $>4$ by an N,S-ligated iron(II) ion, while a zinc(II) ion in the same environment does not show any geometric preference. For $\left(\mathrm{Py}_{2} \mathrm{~S}\right) \mathrm{Fe}^{\mathrm{II}}\left(\mathrm{O}_{2} \mathrm{CH}\right)$, the metal center is already 5-coordinate with a monodentate formate ligand, and thus there is only modest stabilization observed upon moving to a bidentate formate. However, for $(\mathrm{PATH}) \mathrm{Fe}^{\mathrm{II}}\left(\mathrm{O}_{2} \mathrm{CH}\right)$, which most closely mimics the PDF active site, the $\mathrm{Fe}^{\mathrm{II}}$ complex is significantly stabilized by a bidentate formate bonding mode, giving a 5coordinate iron center. It has been previously suggested that the $\mathrm{Zn}^{\mathrm{II}}$ ion in PDF exhibits a preference for a 4-coordinate environment, destabilizing the 5-coordinate intermediate in Scheme $2 \mathrm{~b}$ and causing the lower reactivity of bacterial $\mathrm{Zn}^{\mathrm{II}}-\mathrm{PDF} .{ }^{3,9}$ We propose that it is an inherent geometric preference of Fe $e^{I I}$ for a higher coordination number, which accounts for the much higher reactivity of $F e^{I I}-P D F$ as compared to $\mathrm{Zn}^{I I}-P D F$. This proposal assumes that the release of the formate ligand does not enter into the rate-determining-step, or that the bonding mode does not affect the rate of release, as previously suggested. ${ }^{8}$ Kinetic and mechanistic studies of $\left(\mathrm{N}_{2} \mathrm{~S}\right) \mathrm{M}^{\mathrm{II}}$ model complexes are ongoing in our laboratory to support this idea. ${ }^{13}$

\section{Supplementary Material}

Refer to Web version on PubMed Central for supplementary material. 


\section{Acknowledgment}

This work was supported by the NIH (GM62309 to D.P.G.) and the NSF (CHE-CAREER-0448156 to Y.Z).

\section{References}

1. Lipscomb WN, Sträter N. Chem. Rev 1996;96:2375-2433. [PubMed: 11848831]

2. Baldwin ET, Harris MS, Yem AW, Wolfe CL, Vosters AF, Curry KA, Murray RW, Bock JH, Marshall VP, Cialdella JI, Merchant MH, Choi G, Deibel MR Jr. J. Biol. Chem 2002;277:31163-31171. [PubMed: 12048187]

3. Becker A, Schlichting I, Kabsch W, Groche D, Schultz S, Wagner AFV. Nat. Struct. Biol 1998;5:10531058. [PubMed: 9846875]

4. (a) Rajagopalan PTR, Yu XC, Pei D. J. Am. Chem. Soc 1997;119:12418-12419. (b) Groche D, Becker A, Schlichting I, Kabsch W, Schultz S, Wagner AFV. Biochem. Biophys. Res. Commun 1998;246:342-346. [PubMed: 9610360]

5. Rajagopalan PTR, Grimme S, Pei D. Biochemistry 2000;39:779-790. [PubMed: 10651644]

6. Ragusa S, Blanquet S, Meinnel T. J. Mol. Biol 1998;280:515-523. [PubMed: 9665853]

7. Yuan Z, Trias J, White RJ. Drug Discov. Today 2001;6:954-961. [PubMed: 11546610]

8. Chang S, Sommer RD, Rheingold AL, Goldberg DP. Chem. Commun 2001:2396-2397.

9. Jain R, Hao B, Liu R-p, Chan MK. J. Am. Chem. Soc 2005;127:4558-4559. [PubMed: 15796505]

10. Krishnamurthy D, Sarjeant A, Goldberg DP, Caneschi A, Totti F, Zakharov LN, Rheingold AL. Chem.-Eur. J. 2005Early View, September 6, 2005

11. Addison AW, Rao TN, Reedjik J, van Rijn J, Verschoor GC. J. Chem. Soc., Dalton Trans 1984:1349_ 1456.

12. Hegg EL, Burstyn JN. Coord. Chem. Rev 1998;173:133-165.

13. (a) diTargiani RC, Chang SC, Salter MH, Hancock RD, Goldberg DP. Inorg. Chem 2003;42:58255836. [PubMed: 12971750] (b) Goldberg DP, diTargiani RC, Namuswe F, Minnihan EC, Chang S, Zakharov LN, Rheingold AL. Inorg. Chem 2005;44:7559-7569. [PubMed: 16212382] 


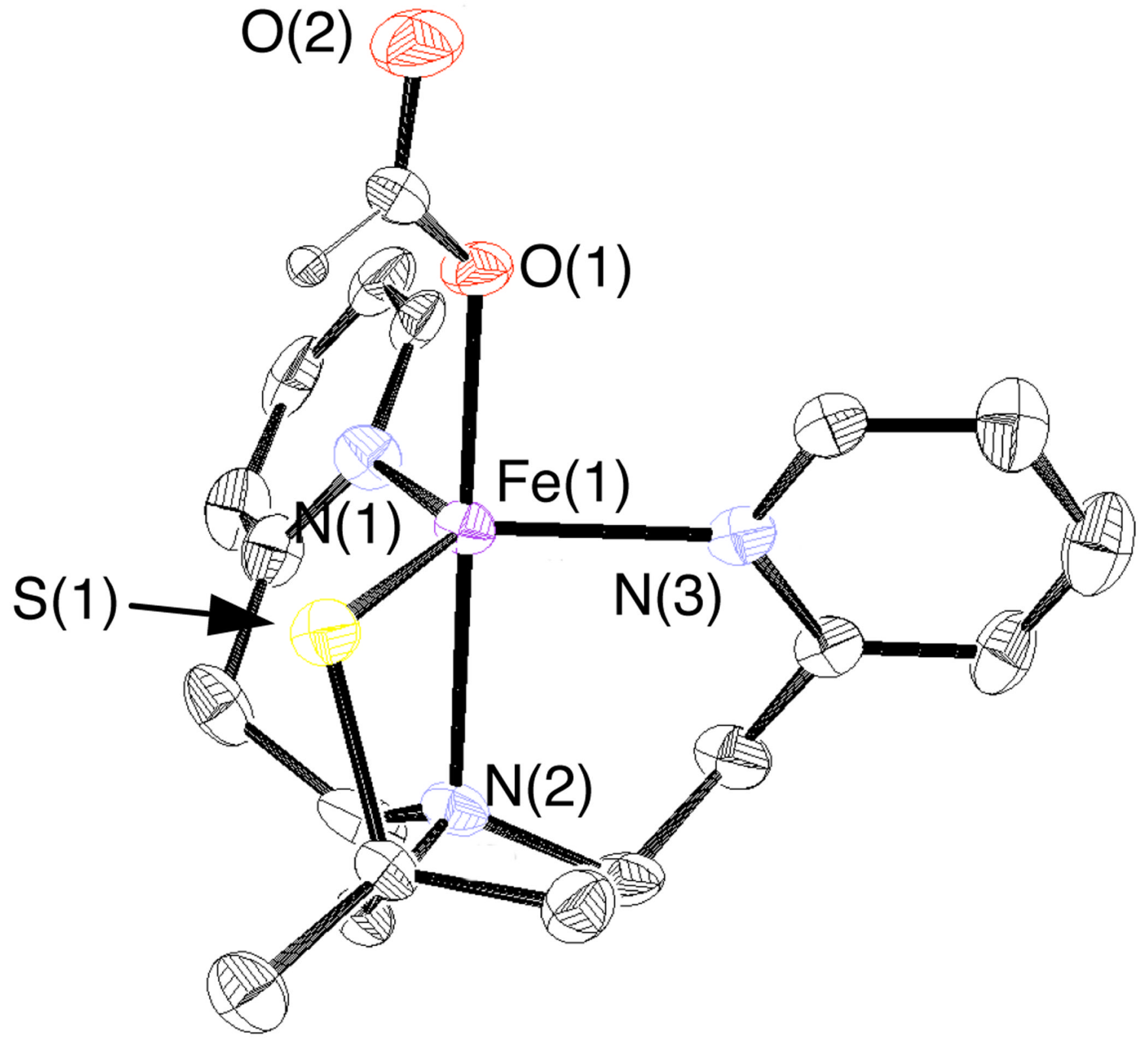

Figure 1.

ORTEP plot of $\left(\mathrm{Py}_{2} \mathrm{~S}\right) \mathrm{Fe}^{\mathrm{II}}\left(\mathrm{O}_{2} \mathrm{CH}\right)$ with $40 \%$ probability thermal ellipsoids. 


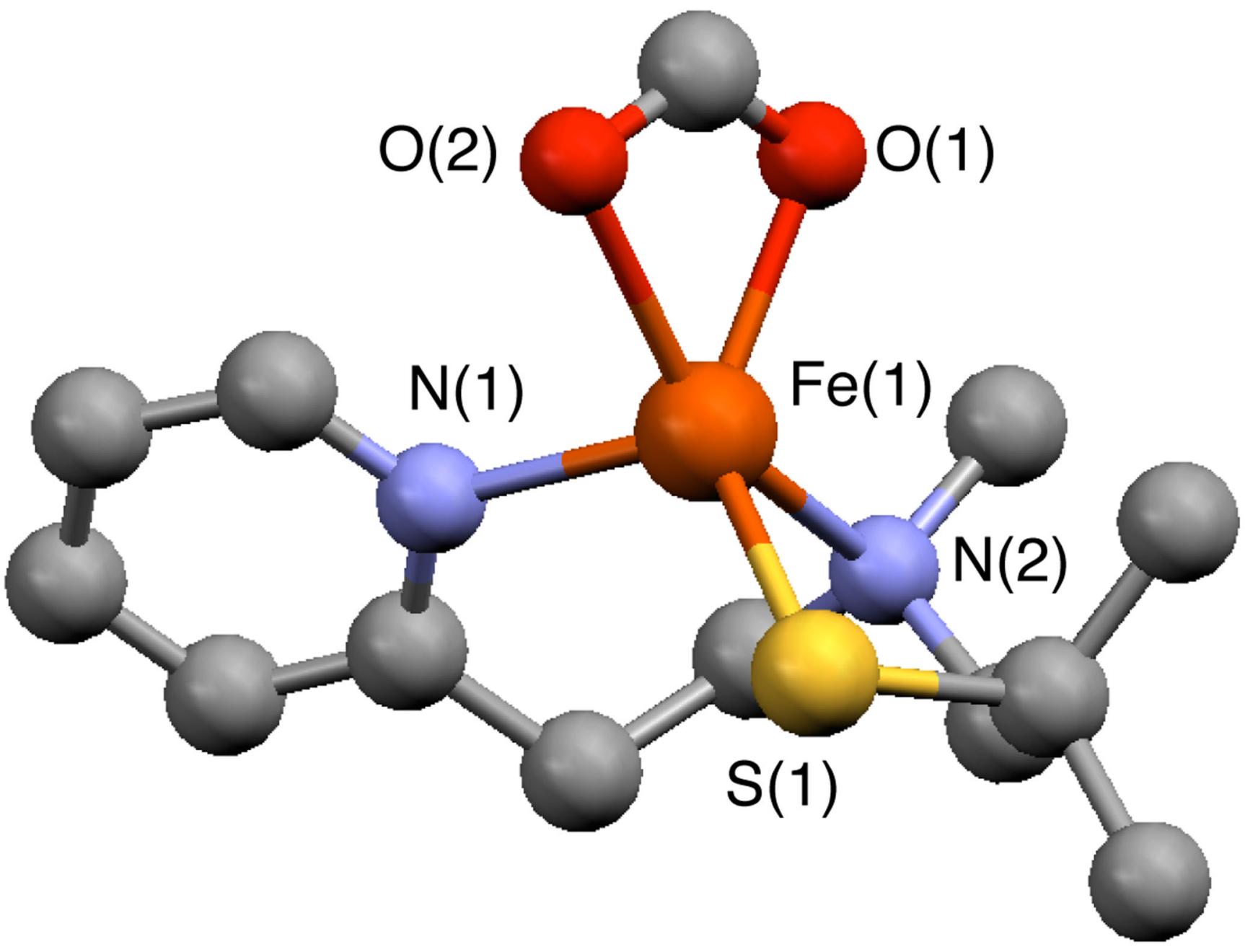

Figure 2.

Geometry optimized structure of $(\mathrm{PATH}) \mathrm{Fe}^{\mathrm{II}}\left(\mathrm{O}_{2} \mathrm{CH}\right)$ from B3LYP/6-311G* calculations. 


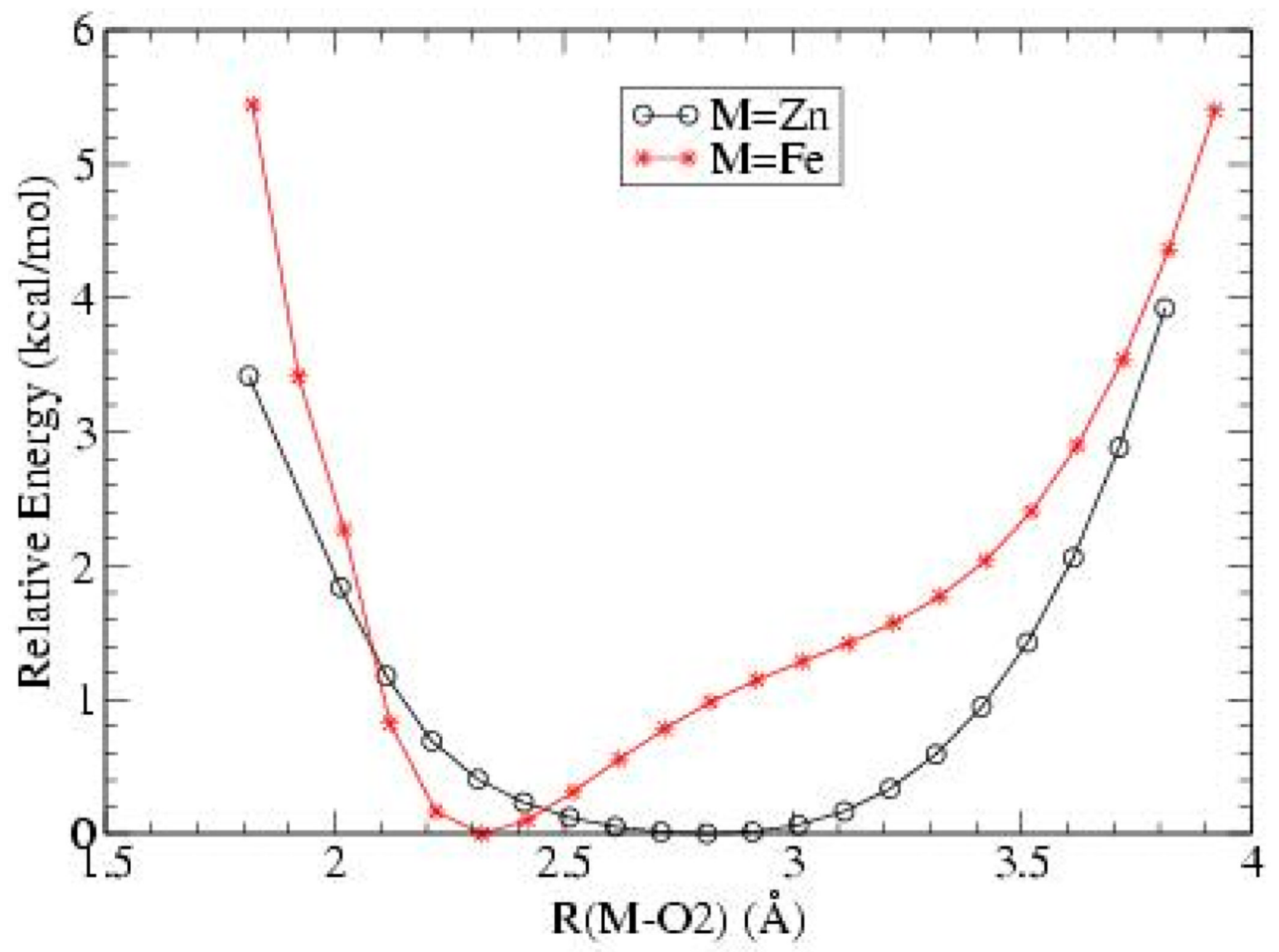

Figure 3.

Potential energy surface of (PATH) $\mathrm{M}^{2+}\left(\mathrm{O}_{2} \mathrm{CH}\right)$ along the $\mathrm{M}-\mathrm{O}(2)$ bond from B3LYP/6-311G* calculations. For each point, geometry optimization has been carried out with the $\mathrm{M}-\mathrm{O}(2)$ bond length fixed. 


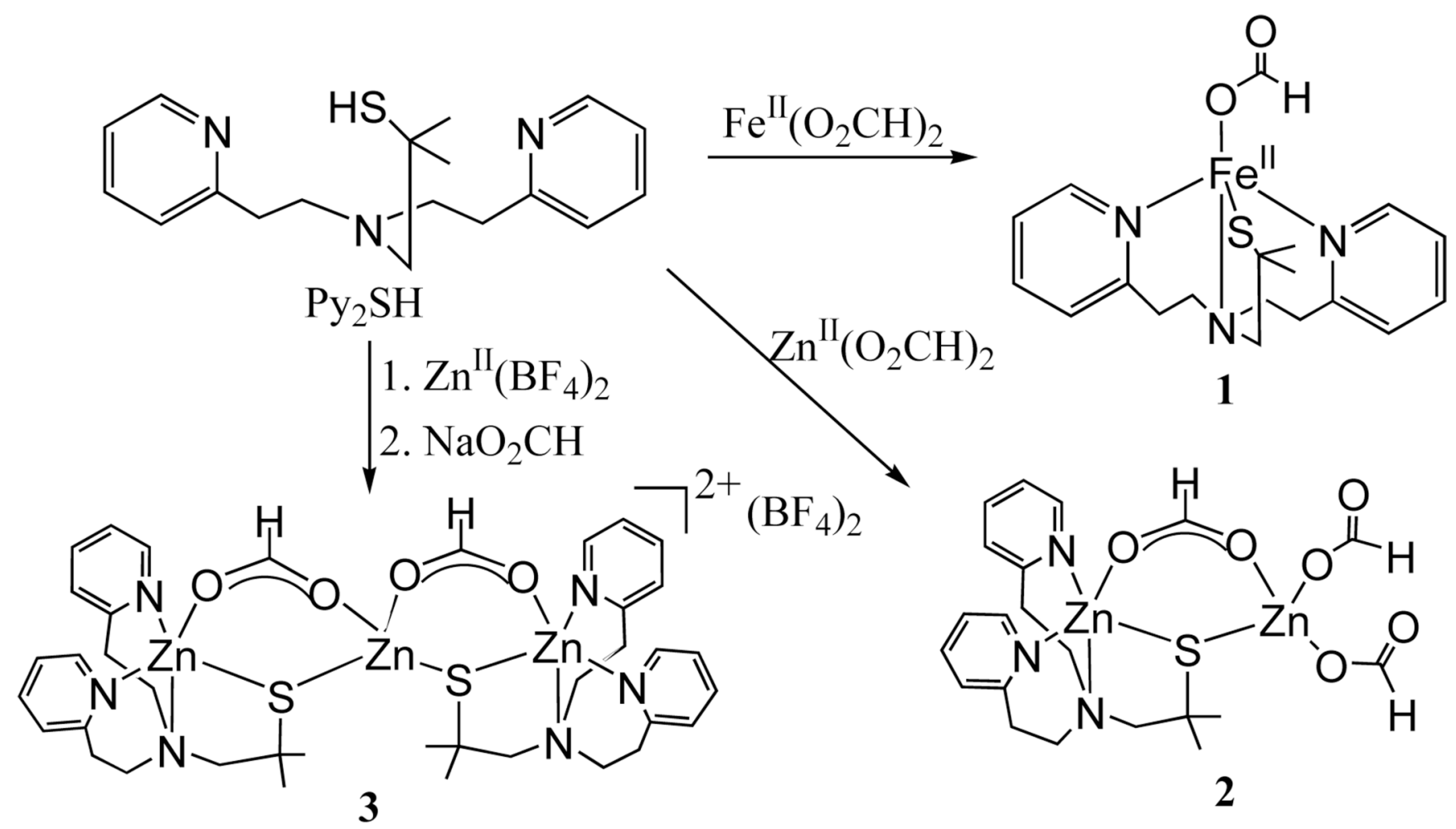

Scheme 1. 
<smiles>CC1CC1NP(N)(N)=O</smiles><smiles>N[W](N)(=S)OCC(=O)NP</smiles>

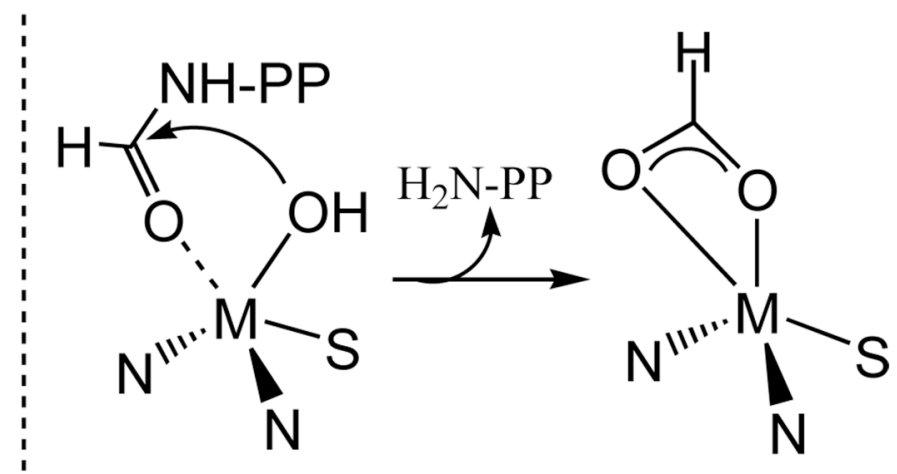

(a)

(b)

Scheme 2. 


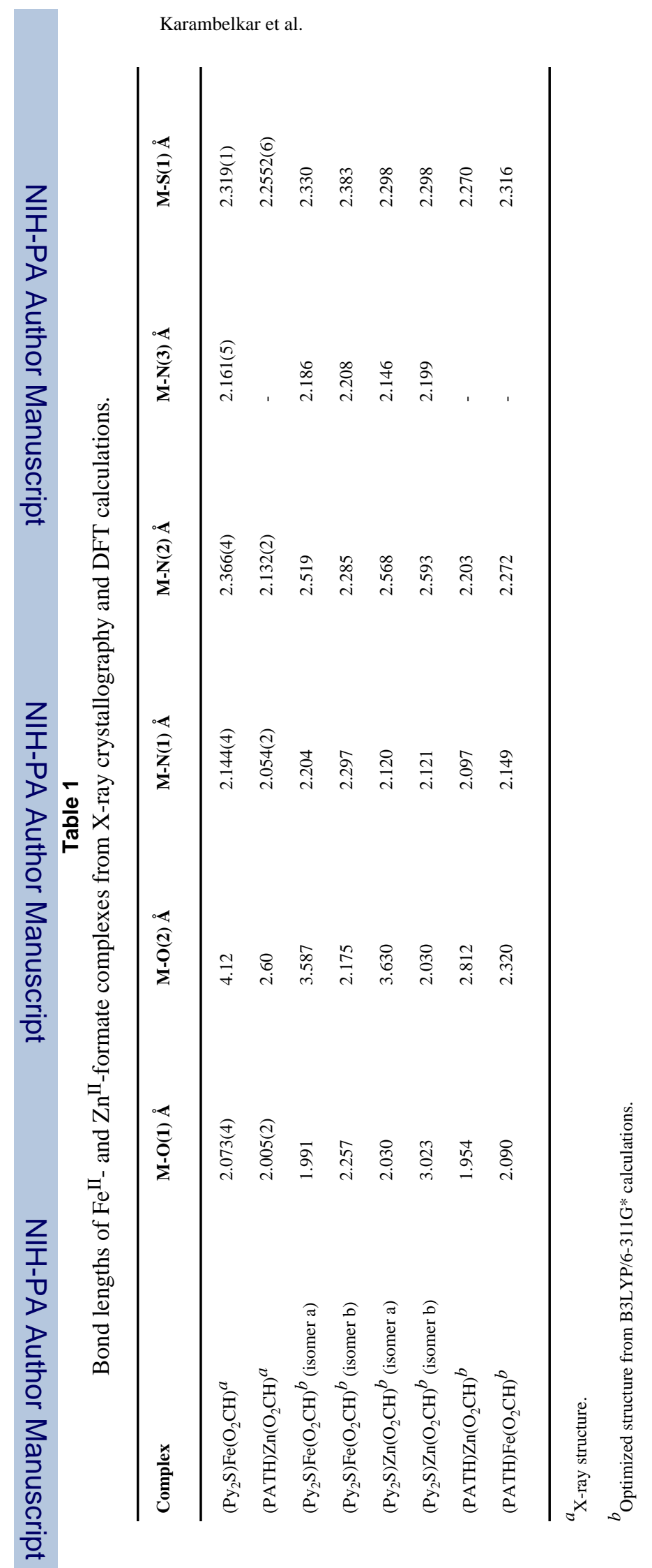

Inorg Chem. Author manuscript; available in PMC 2009 October 12. 